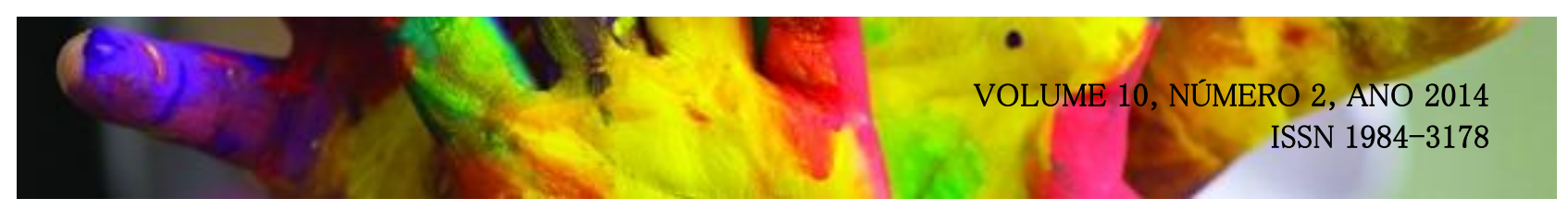

\title{
SOCIABILIDADE E LIVRO DIDÁTICO: REPRESENTAÇÕES DE GÊNERO E SEXUALIDADE NO ENSINO BÁSICO
}

DOI: http://dx.doi.org/10.5965/198431781022014100

Felipe F. Moreira ${ }^{1}$

\section{RESUMO}

O Programa Nacional do Livro Didático e o PCN - Temas Transversais são documentos oficiais que definem os critérios dos livros didáticos a serem incluídos pelas escolas públicas. Através da análise discursiva de 5 (cinco) livros do ensino fundamental e médio (de português, biologia e ciências) adotados no ano de 2009 e 2011, busquei comparar se os livros escolhidos adotavam os critérios de inclusão e diversidade social propostos no PNLD. As orientações antihomofóbicas/antisexistas do programa são claras, porém, ao comparar o que os livros propagavam, quais representações imagéticas e qual discurso estava implicado em suas assertivas, nota-se que não há uma tentativa de inclusão e combate ao preconceito. Atento para a necessidade de maior critério e a inclusão de pessoas capacitadas no momento da escolha dos livros que irão compor o programa e adentrar nas escolas.

Palavras-Chave: Escola; Livro Didático; Diversidade; Discurso; Gênero.

\begin{abstract}
The Programa Nacional do Livro Didático e o PCN - Temas Transversais are official documents that define criteria for books that will be included by public schools. Through the discursive analyzes of 5 (five) books from middle school and high school (portuguese, biology and sciences disciplines) adopted in the years of 2009 and 2011, I sought to compare if those chosen books adopted the inclusive and social diversity criteria that were proposed on the PNLD. The program's antihomophobic/antisexist orientations are clear, but when comparing what the books talked about, which imagetic representations and which discourse was implied in its assertive, we can note that there isn't any attempt of inclusion and fight against prejudices. I call attention for the need of better criteria and the inclusion of capacitated people at the time of the books chosen to compose the program and go inside the schools.
\end{abstract}

Keywords: School; Textbooks; Diversity; Discourse; Gender.

\footnotetext{
${ }^{1}$ Graduado em Ciências Sociais pela Universidade Federal de Viçosa e Mestre em Antropologia pela Universidade Federal de Minas Gerais, Doutorando pela Universidade Federal Fluminense. (21) 979551051. Rua Visconde de Itaboraí, 347 - Niterói - RJ. pileef@gmail.com.
} 


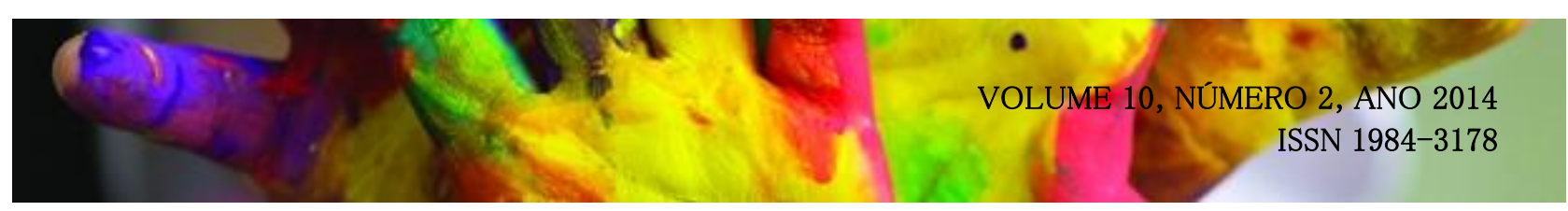

\section{UMA BREVE INTRODUÇÃO}

Inicio pontuando dois aspectos estéticos e políticos deste artigo: Foi escrito em primeira pessoa e sem a utilização de sujeito oculto, artifício comumente utilizado que supõe uma "neutralidade" na escrita científica (difícil de verificar na prática). Mesmo utilizando de mecanismos lingüísticos para exprimir certa neutralidade, a qualquer leitora crítica fica claro que busco problematizar questões que dizem respeito à integridade dos seres humanos, colocando em perspectiva atos discriminatórios de todo tipo, admitindo que possuímos preconceitos difíceis de serem superados e que foram desde cedo internalizados e sancionados por nossos pares. Ressalto que isto não colocou em risco o status da pesquisa, pois ela em si ocorreu por métodos de análise embasados teoricamente e não buscou conformar os dados a alguma prerrogativa, mas sim entendêlos e processá-los de forma acadêmica. Segundo, utilizarei de linguagem inclusiva, alternando os gêneros femininos e masculinos na escrita. Acredito que o constante uso do masculino como linguagem neutra e/ou contemplativa de ambos os gêneros, tanto na escrita quanto na fala, é uma forma de opressão e naturalização de uma instaurada hegemonia masculina. Portanto, em simpatia pelo atraso histórico dos direitos das mulheres e em repúdio à invisibilização do feminino e suas características, tanto na sociedade quanto na literatura, opto por redigir o artigo desta forma. Baseio-me em Furlani (2008, p. 111) na escolha por este estilo literário/político, pois materiais textuais, tanto quanto os livros didáticos dos quais me incumbi de analisar, carregam em seu bojo idéias, saberes, conceitos e categorias que dificilmente conseguem ser neutras politicamente.

O livro didático, como outras formas de comunicação, é um veículo mediador entre concepções de mundo e atos socializadores. Creio ser fértil tal discussão para que consigamos entender o atual quadro de discriminações e sufocamento da diversidade que permeia a escola, instituição esta que funciona como conformadora social, constituída de normas objetivas e subjetivas, definidora de aproximações e afastamentos entre sujeitos de origens e trajetórias sociais diferentes, entendida então como um espaço de negociações de sentidos (DAYRELL, 1996, p. 137). Intento refletir acerca do caráter ideológico presente nos livros didáticos do ensino básico, pois estes, para além de um apoio didático e ferramenta docente, fazem “[...] parte de uma reserva de conhecimento primária que já foi internalizada e cristalizada em atos rotineiros [...]" (NUNES, 


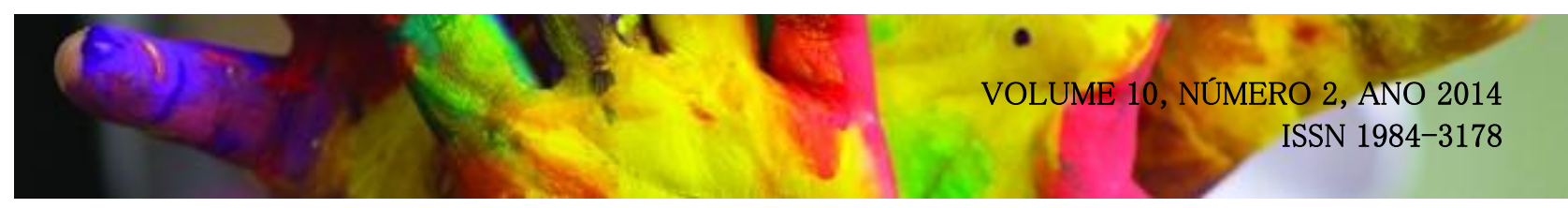

2007, p. 254). Como arcabouço teórico formador e conformador de sociabilidades, é mister nos perguntamos se os livros didáticos conseguem transmitir valores democráticos e humanos básicos de nossa sociedade.

Assim, objetivo comparar os livros didáticos de português, ciências e biologia escolhidos pela E.E Effie Rolfs, do ensino médio e fundamental, com as premissas dos documentos do Programa Nacional do Livro Didático - PNLD. Os itens do PNLD tem preceitos de inclusão da diversidade sexual, autonomia, empoderamento e representação positiva da mulher, diversidade regional entre outros. Portanto, analiso as imagens presentes no interior dos livros em sua articulação com os conteúdos das disciplinas, de forma a ver como se entremeia discurso e ideologia sob a forma de um 'ensino objetivo' que, porém, não se descola de uma visão específica de mundo. É esta visão que, acredito eu, precisa ser colocada em evidência para ver se o que o livro propaga está de acordo com os preceitos do PNLD e não somente, pois a escola em si precisa incentivar a autonomia e promulgar não apenas o crescimento intelectual mas também o crescimento crítico social.

Comparando os dados dos livros didáticos com os preceitos dos editais, através da análise dos discursos do material selecionado e dos estudos de gênero, busquei determinar a dissonância do livro que chega às escolas em relação a determinações para a seleção destes pelo PNLD, via especificações dos editais do programa. Pergunto-me se os preceitos do PNLD realmente são seguidos e os livros que são escolhidos realmente incluem a diversidade nas suas pautas, então cabe analisar os livros escolhidos para nos respondermos estas perguntas.

A importância de se verificar a qualidade dos livros que chegam as nossas escolas se justifica pela importância que estes possuem no processo de crescimento dos alunos e alunas, portanto, buscamos também compreender a natureza da relação entre os discursos textuais e suas articulações com as questões de gênero e sexualidade. 


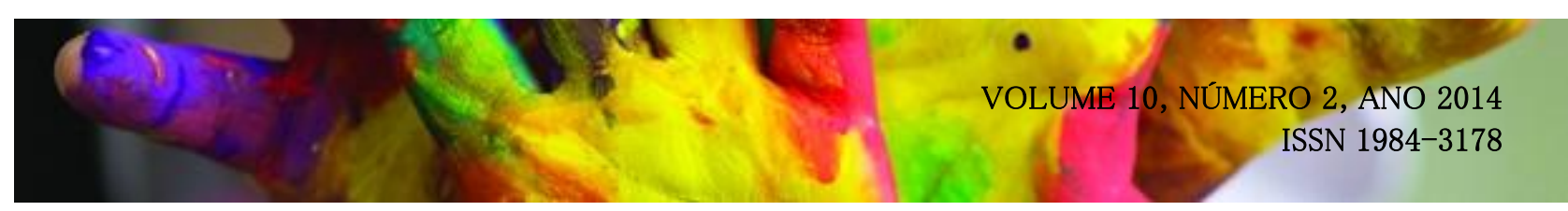

\section{A ESCOLA E AS NORMAS PRESENTES NOS DOCUMENTOS NACIONAIS}

Os Parâmetros Curriculares Nacionais (PCN) - Temas Transversais - têm como princípio a dignidade humana, igualdade social e de direitos, participação e corresponsabilidade social. O que significa isto? Que a educação deve afastar práticas, valores e crenças que desrespeitem estes princípios. Os fundamentos da República brasileira reafirmam a soberania humana, devendo garantir ação cidadã, afastar noções discriminatórias de qualquer tipo e estimular a conscientização para a construção democrática da nossa Nação. O artigo $3^{\circ}$ da Constituição Federal deixa claro que não deve haver preconceitos de origem, raça, sexo, cor, idade e quaisquer outras formas de discriminação. Mas, que outras formas são estas? Segundo o PCN, poderíamos entendê-las através da inserção de novos atores no cenário brasileiro ${ }^{2}$, impondo novos desafios à educação, tendo esta agora uma multiplicidade de agentes-estudantes se matriculando na escola devido à obrigatoriedade do Ensino Médio como etapa final da Educação Básica, se tornando necessário determinar cada vez mais claramente que "outras formas" são estas a ser incorporadas na atualidade.

Também é notável a expansão e criação de diversos projetos (na educação, por exemplo, há o Educação Sem Homofobia, realizado em mais de 5 cidades da região metropolitana de Belo Horizonte) e movimentações sociais (as paradas do orgulho LGBT, por exemplo) que buscam combater estas "outras formas de discriminação" citadas pela Constituição, trazendo luz a discussão pública e inserindo o debate sobre categorias não presentes na Constituição: a orientação sexual e o gênero. Não busco privilegiar as questões de gênero e separá-la das discussões de outras tantas lutas já presentes na arena pública, como raça, classe, religião etc. Diversas publicações (a apostila organizada pela Equipe do Centro Latino-Americano em Sexualidade e Direitos Humanos - CLAM - sobre Gênero e Diversidade na Escola é exemplo disso) já mostraram como tais "características" se interligam de maneira complexa e se articulam de diversas maneiras tanto teoricamente quanto socialmente. Mas o nosso recorte visa explorar, como tema central, o gênero e a orientação sexual, localizando estes temas e suas representações (e invisibilidades) nos materiais didáticos escolares.

\footnotetext{
O próprio PCN já busca dar mais solidez à estas "outras formas": "Novos atores, novos direitos, novas mediações e novas instituições redefinem o espaço das práticas cidadãs, propondo o desafio da superação da marcante desigualdade social e econômica da sociedade brasileira, com sua conseqüência de exclusão de grande parte da população na participação dos direitos e deveres." (BRASIL, 1998, p. 20).
} 


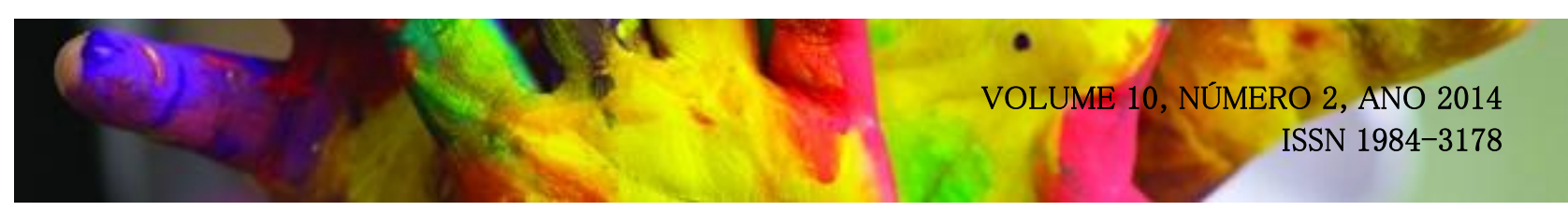

Os editais do Programa Nacional do Livro Didático (PNLD) analisados aqui foram os de 2011 (ensino fundamental - anos finais) e o Catálogo do PNLEM (Programa Nacional do Livro Didático para o Ensino Médio) de 2009. Estes documentos são claros e criteriosos ao tratar do tema da discriminação em suas linhas, inclusive, em alguns momentos, avançando na discussão sobre orientação sexual focando o combate à homofobia, numa clara tentativa de superar o atraso Constitucional que relega a sexualidade a "outros" tipos de discriminação, não dando nome nem explicitando a categoria. O edital de 2011 afirma que uma sociedade cidadã necessita não só respeitar a diferença de gênero, mas abordar o tema, enfatizando positivamente a imagem da mulher, evitando estereótipos e combatendo a misoginia. Nas especificações por área, de Geografia e Língua Estrangeira Moderna, presentes no edital, prima que estas disciplinas devem reconhecer e abordar a pluralidade social de forma respeitosa e serem isentas de preconceitos, seja de origem, etnia, gênero, religião, idade ou orientação sexual (porém, na área de Geografia, o termo "sexualidade" também está dentro de "outras formas de discriminação", ao contrário das disciplinas de Inglês e Espanhol - Língua Estrangeira Moderna - onde deixam claro que, quando relevante, a professora deve trabalhar questões de orientação sexual em sala de aula).

As duas diretrizes presentes nos editais desta disciplina possuem esta mesma linha pedagógica ao trabalhar a diferença, buscando não só por tolerância, mas respeito - conceitos bem diferentes, a serem discutidos mais adiante - e interesse pelo assunto, tendo os livros escolhidos pelo programa que abordar a diferença em seus conteúdos e tematizá-la sob diversos ângulos, desenvolvendo a ética de um convívio social, cidadão e inclusivo.

Ressalto aqui alguns pontos entre o edital do PNLD de 2011 e o Catálogo do PNLEM de 2009. Os critérios de eliminação das obras didáticas são claros afirmando estarem fora do PNLD obras que veicularem estereótipos e preconceitos de gênero e orientação sexual (além de idade, condição social, raça e etnia, etc.). O Catálogo do PNLEM de 2009 avança em pontos importantes com relação aos critérios específicos por área. Não consta o termo/conceito "orientação sexual" nos critérios de Geografia no edital de 2011 do ensino fundamental enquanto em nos Catálogos de 2009 para o PNLEM, incluindo a área de Geografia, o termo “orientação sexual” aparece. Interessante constatar que o edital consolidado de 2012 do PNLD do ensino médio (nas páginas 38 e 39) 


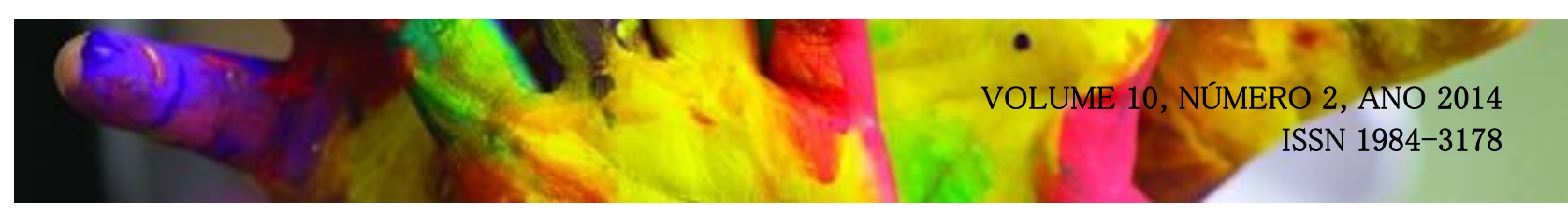

explícita a diferenciação entre sexo e gênero no seu conteúdo específico de Biologia, análise frutífera para o movimento feminista e LGBT a partir da década de 60 e que proporcionou o alavanque dessa discussão, enfatizando o papel social na construção do gênero e descreditando uma suposta preponderância biológica. Este edital único para o ensino médio entra em ação a partir de 2012 para unificar as disciplinas sob um único documento e acredito que então haverá menos dissonância entre os editais até então lançados. Mas não deixa de transparecer até então certa descontinuidade na elaboração dos critérios e preceitos éticos presentes nos documentos que regulamentam a participação dos livros didáticos no programa do governo, pressupondo uma falta de diálogo entre aqueles que os elaboram.

Os critérios comuns do PNLD 2011 deixam claro que a orientação sexual e sua veiculação negativa nos materiais constituem eliminação para as obras que assim a veicularem, porém, em seus critérios específicos na matéria de Geografia, este termo desaparece e logo em seguida reaparece nas linhas dos editais referentes à disciplina de Língua Estrangeira Moderna. Tal como na Constituição, a interpretação de "... outras formas de discriminação." como contemplando a orientação sexual é problemática no sentido de que, ao não explicitar o termo, deixa margem a interpretações oportunistas ou até mesmo a invisibilização da questão. Este distanciamento na discussão das diferentes disciplinas nos editais não ocorre apenas de forma subentendidas ou opacas, mas qualitativamente afeta o teor da discussão. A generalidade dos critérios específicos de Língua Estrangeira Moderna é tão rica quanto o edital em si, pois explícita o reconhecimento da identidade alheia, coletiva e individual, deixando claro que seu conteúdo não deve conter textos ou imagens homogêneas, transparecendo a heterogeneidade nacional, de gênero, de classe social etc. Apesar de a discussão ser bem avançada em alguns pontos, são formulações teóricas que visam moldar materiais concretos, materiais estes que presto a análise, buscando compreender a dinâmica entre normatizações do governo e como "colorem" os livros escolhidos pelas escolas. Ou seja, como a "teoria" se imprime na realidade. Os princípios antidiscriminatórios tanto do PCN quanto no catálogo e edital do PNLD são claros, mas como o mercado editorial tem abraçado tais diretrizes?

Muito mais que "recomendações", são apontadas não só critérios de eliminação, mas linhas 


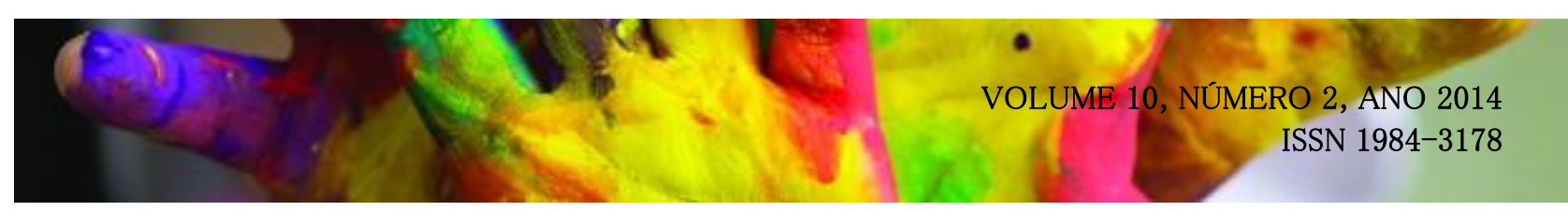

que deveriam orientar a construção de um material didático democrático e igualitário, representacional e enriquecedor. Apesar de certa descontinuidade de preceitos de uma disciplina para outra nos editais, ainda assim eles possuem diretrizes progressistas interessadas na construção de um país igualitário e justo, mas nos prestemos a algumas perguntas: Como se dá o diálogo entre teoria e prática (o que o edital define e o que realmente chega nas escolas)? Os livros que chegam às escolas respeitam os princípios explicitados nos documentos oficiais da União? Mesmo em um cenário educacional onde os livros fossem inclusivos e abordassem de forma significativa a diferença, estaria o corpo docente preparado para utilizá-los de forma efetiva?

Por mais que os critérios e orientações dos documentos do PNLD avancem em direção a uma concepção libertária de sociedade, seu caráter é mais prescritivo do que pedagógico. O objetivo deste artigo não é discutir a formação docente, apesar de ser um ponto importante, pois deixo claro que não tenho a visão ingênua de que bastam livros que ilustrem diferentes tipos de união sexualafetiva ou minorias exercendo papéis protagonistas na sociedade para que a realidade mude "positivamente". A dinâmica escolar se faz sob diversos ângulos e atento aqui apenas para um dos aspectos de sua estrutura. Estrutura esta que não deve comportar uma noção de tolerância em relação a quem é considerado diferente ou até mesmo taxado com este adjetivo. Trabalhar com o respeito é dar poder, possibilitar a conscientização de que o sujeito é um agente, deixar claro que a história, seja local, como na escola, ou regional e nacional, é um processo em permanente construção. O respeito aponta na direção de uma descentralização de poder, tende a horizontalizar as relações enquanto a tolerância não só reafirma como também produz a hierarquização, pois se "simplesmente toleramos o outro, exercemos o poder de suportá-los com suas práticas." (FELIPE; BELLO, 2009, p. 152), nascendo então uma pretensa superioridade que nos dá a ilusão de praticarmos um altruísmo relacional frente a quem "permitimos" ser o que é.

A tolerância gera um assistencialismo que não traz a diversidade pra pauta escolar, só a constatação da diferença de forma valorativa. Se a diferença e a diversidade necessitam sempre da benevolência daqueles que as permitem "existir", não só se encontra em uma posição frágil, mas também são vistas com desrespeito, já que dependem de terceiros para prevalecer. 


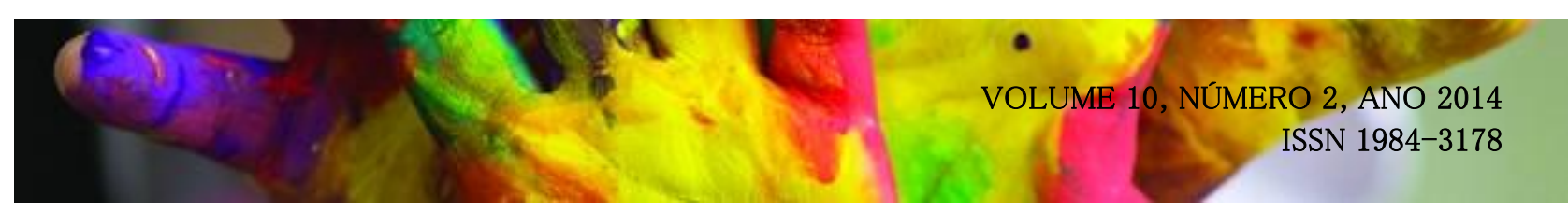

Antes de passarmos para a análise dos livros selecionados como amostragem, precisamos definir o conceito de heteronormatividade e a sua relação com a escola e o livro didático, pois acredito que tais diretrizes, recomendações e linhas de combate à discriminação por gênero e orientação sexual têm justamente como propósito combater a heteronormatização da sociedade e seus efeitos históricos que abafam a voz da diferença e confinam a diversidade como um "problema" que nunca se vai e que temos que conviver problematicamente.

\section{REPRESENTAÇÕES SOCIAIS NA ESCOLA E NO LIVRO DIDÁTICO}

Cabe-nos conceituar um dos nortes deste trabalho, a heteronormatividade: consiste em práticas, idéias e discursos que tendem a estabelecer as relações heterossexuais como naturais, benéficas e necessárias à sociedade. Isto acontece através da valorização do papel heterossexual em suas diversas formas de atuação e se conecta também ao sexismo, excluindo as possibilidades de identidades díspares das determinadas socialmente pelo pretenso discurso do sexo biológico, implicando arbitrariamente uma relação socialmente forjada entre sexo e comportamento social. A feminilidade se associa à submissão, contenção de impulsos, recato e necessidade de proteção, sempre à espera de auxílio. Ser masculino é tomar a frente, não demonstrar emoções, ser duro e prover ao lar. A heteronormatividade busca nos introjetar e internalizar estas idéias que centram a relação heterossexual (homem-mulher) como núcleo estruturador do mundo ao mesmo tempo em que hierarquiza as relações e subcategoriza (ou até mesmo esconde) outras formas possíveis de interações e vivências, tais como as de orientação homoerótica.

O senso comum relega a diversidade existente do humano a formas universalizantes de ser/estar, buscando padrões e continuidades temporais e geográficas que expliquem o comportamento social como "correto" ou ideal (tanto no sentido de modelo quanto de realidade). Não só na escola, mas em todos lugares se torna imprescindível compreendermos o choque do senso comum com a diversidade, pois as articulações e potencialidades do gênero e da sexualidade não são e nem nunca foram coerentes ou sólidas. Ao contrário, justamente por causa de contextos políticos e econômicos foi que nos iludimos com uma suposta homogeneidade: 


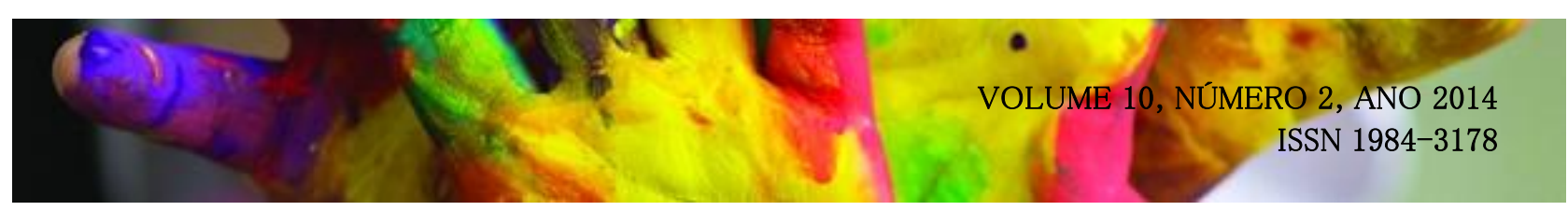

“[...] o gênero nem sempre se constituiu de maneira coerente ou consistente nos diferentes contextos históricos, e porque o gênero estabelece interseções com modalidades discursivamente construídas. Resulta que se tornou impossível separar a noção de "gênero" das interseções políticas e culturais em que invariavelmente ela é produzida e mantida." (BUTLER, 2008, p. 20).

No atual contexto de uma sociedade brasileira heterogênea e marcada por diferenças de classe, étnicas, religiosas, etc., como apontam os Parâmetros Curriculares Nacionais, as inúmeras continuidades e descontinuidades que configuram o sexo, o gênero e a sexualidade devem ser pensadas como possibilidades e não anomalias. Devem se desvincular da noção enraizada que define o gênero e a sexualidade de acordo com o sexo biológico. Para Junqueira (2009, p. 183), as relações entre identidade de gênero, sexualidade e sexo são múltiplas e desejáveis e a sociedade deve não descreditar, mas atentar para as inúmeras “[...] possibilidades, descontinuidades, transgressões e subversões que o trinômio sexo-gênero-sexualidade experimenta e produz."

As formas óbvias que o senso comum normatizador formula para perpetuar seu padrão comportamental podem ser encontradas em exemplos e/ou ilustrações presentes no livro didático onde a mulher é representada sempre como dona-de-casa ou em profissões estereotipadas (professora, enfermeira, cozinheira, etc. sempre área da educação ou saúde e ainda assim, em subáreas dentro destas) ou nas representações de famílias visivelmente "estáveis", parcimoniosas, onde há uma mãe, um pai, filhos e filhas, algum animal de estimação e uma casa luxuosa. Não é preciso dizer que são todos brancos, bem vestidos, bem humorados e financeiramente estáveis.

Estas representações tendem à exclusão de formas dissidentes, criando um referencial hegemônico e opressor a ser seguido, seja de família, de identidade/comportamento, possibilidades econômicas ou de ações diárias. É preciso analisar como o discurso presente nos textos, para além dos exemplos e ilustrações, nos conceitos e nos encadeamentos lógicos de raciocínio existentes nas diversas matérias contribui para esta visão de mundo não inclusiva. É também comum o uso do masculino como linguagem neutra no português coloquial e culto. São sempre "os" professores, "os" alunos, "os" homens etc., que servem de substantivo para guiar as orações textuais. Ora, se, como no inglês, existisse mesmo tal flexão neutra (the teacher, the students, etc. onde não há uma 


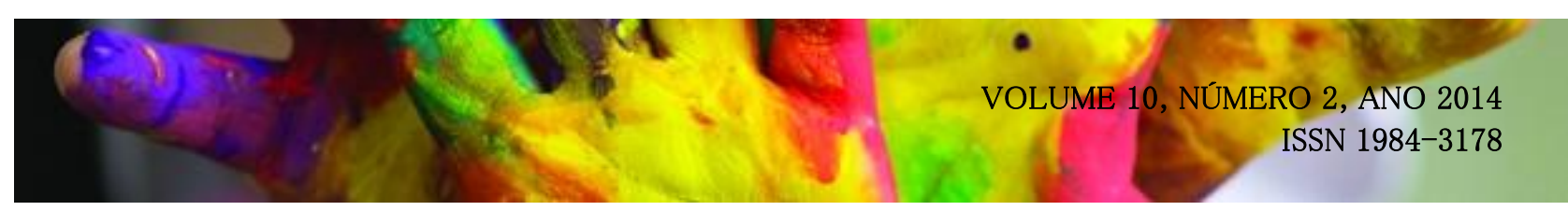

distinção de gênero, o artigo é neutro), não haveria necessidade de termos a palavra "professora", "aluna" ou "mulher" em nosso vernáculo, sendo que sua contraparte masculina seria suficiente para guiar e compor as frases. A semântica é importante principalmente porque compõe a análise semiótica (relação sintaxe-semântica), o que nos aponta para a relação entre significado e significante, entre quem emite e define a linguagem e a que ela presta. Então a face opressora da nossa linguagem fica evidente quando, mesmo existindo como opção diversos substantivos que representem o gênero feminino e lhe dão visibilidade, ainda assim escolhemos falar no masculino em todas as situações.

Quando se trata de linguagem culta, a semiótica é essencial para que a compreendamos, pois estuda o choque entre a sintaxe e a semântica. Já na linguagem coloquial, a semântica deve ser mais explorada por tratar da vivência efetivada, de relações acontecendo em tempo real e de formalidades casuais e estabelecidas pelo contexto, e não pela regra gramatical. Temos assim um conflito para explorar, pois, como se dá então este choque entre a linguagem formal e a comunicação efetivada? O livro didático é um fator essencial para explorar esta idéia já que, se tratando de ensino público, é um dos poucos, senão o único livro que alunas e alunos têm acesso durante sua vida. Por ser um dos poucos ou únicos contatos literários, a qualidade deste contato é fator importante a ser levado em conta, pois: "Uma experiência frustrada com o livro didático (às vezes o único livro a que a criança tem acesso) pode afastar essa criança da leitura." (SEC. DE EDUCAÇÃO DO ESTADO DE SANTA CATARINA, 1999, p. 5).

Além da forma de escrever e articular o gênero masculino na escrita reificando o predomínio masculino, as gravuras servem de reforço heteronormativo, naturalizando posturas e comportamentos que nem sequer pensamos serem construídos (se percebêssemos o caráter construtivo de tais relações, a desconstrução seria também uma idéia presente). Este processo de formação não está somente nos livros, mas na escola, na família, na igreja e em demais instâncias sociais que contribuem tanto pra naturalizar o comportamento como quanto para torná-lo indetectável ao questionamento ${ }^{3}$. O livro didático é um dos braços que ajudam a manter o status

A exclusão da diversidade nos livros gera a invisibilidade, o sentimento de não pertencimento reforçado pela rotininização do comportamento padronizado: "Os heterossexuais não se dão conta de que eles, rotineiramente, 


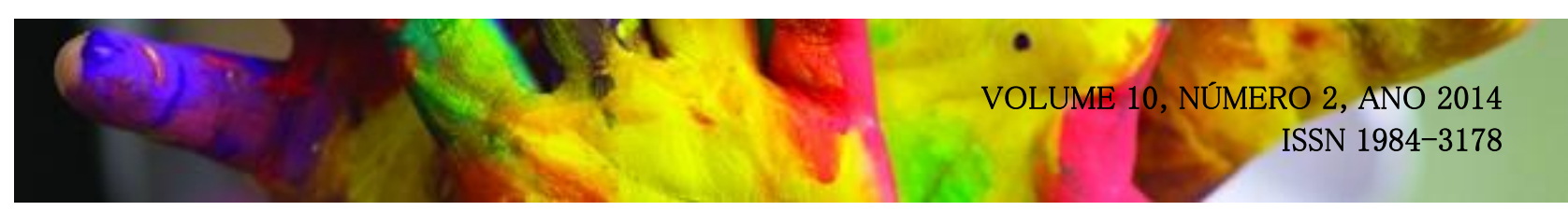

quo heterossexual e masculinizado presente na sociedade ${ }^{4}$. Dentro desta ótica, a escola e seus componentes, desde o uniforme, o formato das salas de aula, as normas de circulação dentro de seus pátios, a forma de trabalhar o esporte nas aulas de educação física, e, por fim, os livros didáticos, contribuem para esta forma naturalizada (e neutralizada) de ver um mundo onde se nasce homem ou mulher, determinando de que só há uma forma certa de viver a vida em sociedade: heteronormatizada, norteada pela combinação lógica entre gêneros opostos, tendo por certeza que o homem será "masculino" e "a" mulher será "feminina". Este processo de formação tende tanto a minar as possibilidades já existentes, mas invisibilizadas, como compactar as possibilidades de transgredir as normas comportamentais e inventar novos rumos e personalidades.

Assim, não podemos entender o crescimento do aluno como um processo de construção próprio de sua identidade, mas sim como um "bricolage" de características já existentes na sociedade que ele vai aderindo à sua persona. Este bricolage é muitas vezes visto como autônomo e falseado por noções egocêntricas como o mito de que "basta querer" para conseguirmos ser quem gostaríamos de ser na vida. Porém, o que imaginamos como um "eu" constituído por emoções, ações, procedimentos inter-relacionais, etc., pode muito bem ser uma realidade causal, constituída por uma "[...] ficção socialmente construída (ainda que séria), como um produto da linguagem e de discursos específicos relacionados a compartimentos do saber.” (SPARGO, 2006, p. 46-47).

Cabe uma consideração também que a lógica da construção da personalidade não é a mesma para homens e mulheres, tal como não é para negros e brancos, etc. A sociedade disponibiliza elementos pré-definidos e discriminatórios não só binariamente, e estes elementos se agregam cada vez mais, perpetuando um ciclo de discriminações que limita progressivamente o grau de atuação e possibilidades das pessoas no mundo. A criatividade na elaboração de identidades dissidentes do

discutem aspectos de suas próprias sexualidades cotidianamente: contando para seus colegas sobre as férias que tiraram com seu/sua parceiro; explicando para os seus chefes que estão passando por um divórcio difícil; gabando-se do seu novo romance para os amigos" (SANTOS, 2007, p. 6).

4 Seja através dos livros didáticos, das brincadeiras no recreio, da formação que os docentes recebem e passam em sala de aula e nos pátios, na escola não se transmite apenas conhecimento mas atualmente, o faz "[...] reproduzindo padrões sociais, perpetuando concepções, valores e clivagens sociais, fabricando sujeitos (seus corpos e suas identidades), legitimando relações de poder, hierarquias e processos de acumulação.” (JUNQUEIRA, 2009, p. 14). 


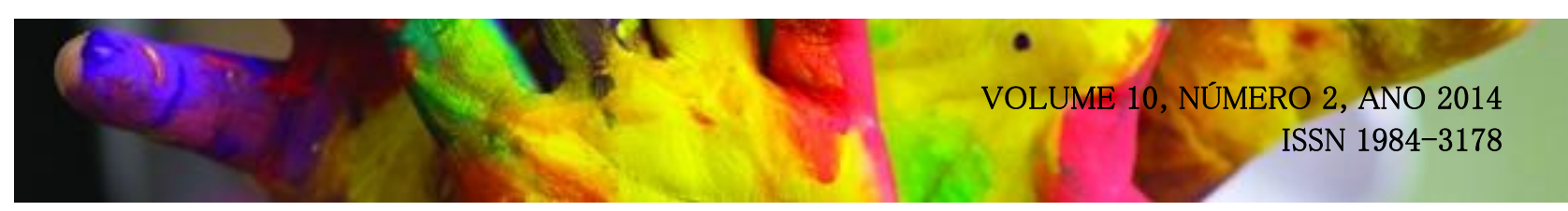

que é esperado não só sofre repúdio pela sociedade, mas tende a jogar no ostracismo aquelas que ousam transgredir a norma. Se a inventividade para criar novas identidades já não é valorizada, muito menos a é para quem se afasta cada vez mais do que é esperado socialmente.

O livro didático está presente no dia a dia dos alunos e alunas, seja na escola ou em casa, durante toda sua formação escolar e, no caso dos estudos continuados, no vestibular e na universidade. É um constante na formação educacional individual e coletiva, pois quando não estamos acompanhados de livros, estamos socializando com pessoas que provavelmente passaram pelos mesmos processos escolares que dependeram destes livros. Em escolas diferentes, em lugares diferentes e até mesmo com pedagogias diferentes, o livro está presente. Somos alfabetizados utilizando livros didáticos e nos comunicamos a partir do que aprendemos em determinado contexto escolar. Assim, é preciso atentar para as nuances desta linguagem, principalmente em um ambiente de formação humana, como a escola.

Estas nuances não são apenas maneirismos ou especificidades regionais. Falo da explicitação de palavras e articulação de frases que carregam preconceitos e estereótipos passíveis de abafar a fala de quem é vinculado a tais discriminações:

\footnotetext{
"Dentre os múltiplos espaços e as muitas instâncias onde se pode observar a instituição das distinções e das desigualdades, a linguagem é, seguramente, o campo mais eficaz e persistente - tanto porque ela atravessa e constitui a maioria de nossas práticas, como porque ela nos parece, quase sempre, muito 'natural'." (LOURO, 2010, p. 65).
}

Quando se reafirma constantemente, e não só na escola, que certas características são masculinas e outras femininas (onde geralmente as femininas estão abaixo na hierarquia), que certas cores são para homens e outras para mulheres, que certas atitudes praticadas por homens são normais e quando praticadas por mulheres são abomináveis, por fim, quando se define diariamente o que é e o que não é permitido, quando se delineia uma série de características desejáveis para homens e mulheres (em conformidade com a heterossexualidade compulsiva), percebe-se um estreitamento de possibilidades identitárias e a naturalização de pressupostos dominantes e hierarquizadores que conformam as práticas cotidianas e marginalizam suas dissidências. A linguagem, no caso, atua dentro deste espectro, ao ser utilizada não só para manter certas 


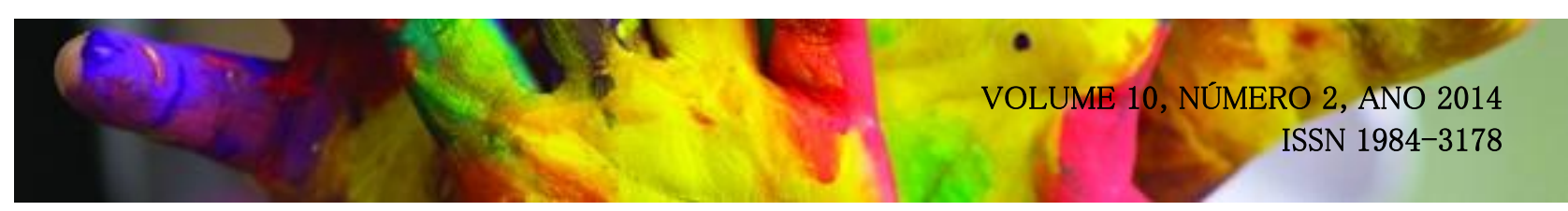

características dentro do esperado mas também quando certas palavras ou gestos não são utilizados regularmente, constituindo exceções e exemplos do que não se deve ser/fazer.

Neste processo de exposição e formação discente, não somente o livro, mas também a televisão, a internet etc. corroboram este mundo pré-determinado pelo sexo biológico e por pressupostos culturais já muito estabelecidos e rígidos, não havendo muitas opções do que usar para constituir a personalidade de alguém ou até mesmo a possibilidade de se analisar e escrutinizar aquilo que se deseja ter/ser, muito menos “inventar” algo que já não seja reconhecido. Não entendo tal "escolha" pela primazia da razão, de forma clara e deliberativa, pois não é fácil assim definir o que escolhemos e o que achamos que escolhemos inconscientemente e nem é este o foco destas reflexões, mas devemos atentar para o potencial que o livro didático tem neste processo de crescimento humano, de possibilidades de representações sociais que outorga verdadeira sobre o mundo. Até então os livros didáticos não tem incluído representações de gênero e sexualidade que reflitam a realidade múltipla que vivemos e as inúmeras formas não padronizadas de família que existem:

\begin{abstract}
"Nos livros didáticos, o caráter heteronormativo das relações sociais está presente nos padrões de representação de gênero e de organizações familiares, nos discursos sobre afetos e também na ausência do tema da diversidade sexual. A heteronormatividade impõe um silêncio sobre essa temática: não há gays nas obras literárias, não há relações homossexuais nos textos de orientação sexual e, muito precocemente, as crianças aprendem a indexar o universo social pela dicotomia de gênero. (LIONÇO; DINIZ, 2009, p. 52).
\end{abstract}

Acredito que através da sistemática exposição ao livro ${ }^{5}$ em sua forma específica de escrita (a já mencionada tendência à representação do gênero masculino como neutro na escrita) e suas figuras exemplificadoras (as gravuras estereotipadas de mulheres e homens em profissões e situações ligadas ao seu sexo biológico, as afetividades heterossexuais, etc.) é que há este achatamento de possibilidades no vir a ser da pessoa e uma falta de representações que empodere

\footnotetext{
${ }^{5}$ A repetição sistematizada pode ser entendida como um valor de reforço hegemônico, uma forma de manter aquilo que já é tido como certo, evitando seu desfacelamento: "O processo de repetição é tanto uma reencenação e uma reexperimentação de uma série de significados já socialmente estabelecidos, quanto a forma mundana e ritualizada de sua legitimação." (SPARGO, 2006, p. 52-53).
} 


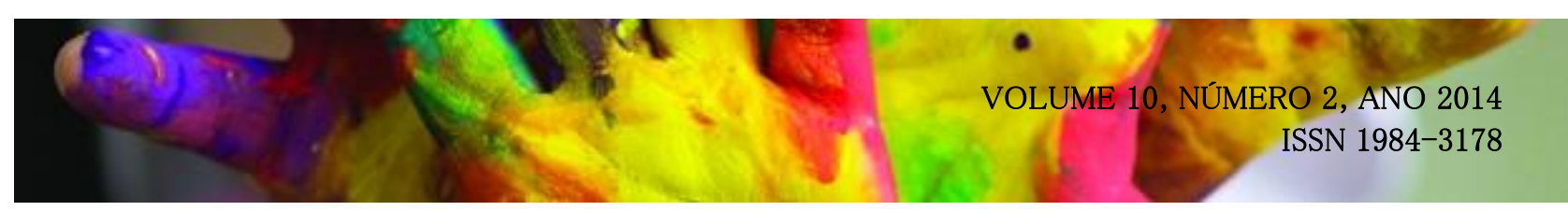

sua própria personalidade e vivência díspar do que se vê nos meios de comunicação e nos exemplos sociais. A importância do livro didático neste processo de formação e seu caráter normativo são às vezes postos em segundo plano. Não devemos atribuir ao livro um papel coadjuvante ou vê-lo como sintomático da desigualdade já presente na escola e na sociedade no geral, mas vê-lo como agente de mudança ou acomodação, dependendo do seu uso.

A abordagem que me presto é de que o livro e a linguagem escrita não são só componentes deste processo de formação, mas também determinantes deste. Os materiais pedagógicos escolares, ao mesmo tempo em que reafirmam as práticas e pessoas vistas como "normais" e asseguram sua vivência, também estigmatizam as “[...] 'desviantes', 'não-autorizadas', 'anormais', (por exemplo, para muitos, ainda, o relacionamento sexual e afetivo entre pessoas do mesmo sexo - a homossexualidade; ou, ainda, a 'suposta inversão' de gênero - homens femininos e mulheres masculinas)" (FURLANI, 2008, p. 112). A própria invisibilidade e a falta de nomeação serve para jogar à margem os que não possuem nome, mas são agrupados e agrupadas sob a sigla do "desvio". A experiência marxiana via na linguagem um dos pilares da desigualdade e acreditavam ser imprescindível que esta se transformasse para que houvessem mudanças sociais significativas. Para Trotski (1981, p. 60): “A cultura lingüística é a condição mais importante para o desenvolvimento de todos os setores da cultura, em particular da ciência e da arte".

Por considerar a cultura linguística como importante e pelo livro didático ser uma expressão da cultura linguística de nossa sociedade, parto do pressuposto que os seus discursos imbuídos servem para mostrar a atual situação do debate social, tanto escolar quanto mais amplo. Os discursos presente em nossos materiais didáticos mostra, como Fairclough (2001) crê, tanto a dinâmica histórica da constituição das hegemonias e lutas por mudança quanto a construção social do discurso oficial e marginal, de forma que uma análise de discurso crítica deve preocupar-se "não apenas com as relações de poder no discurso [...] mas também com a maneira como as relações de poder e a luta de poder moldam e transformam as práticas discursivas de uma sociedade ou instituição[...]" (p. 58). A escola é uma destas instituições e, como o autor supracitado, busco "uma análise de discurso que focalize a variabilidade, a mudança e a luta: variabilidade entre as práticas e heterogeneidade entre elas como reflexo sincrônico de processos de mudança histórica que são 


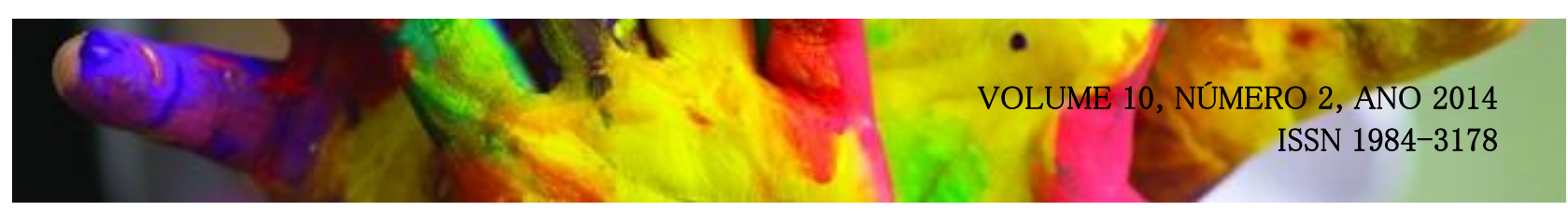

moldados pela luta entre as forças sociais.”.

A já mencionada pluralidade de agentes no cenário educacional dificulta, ou até impossibilita, a mensuração precisa de como e em que grau uma ou outra aluna é atingida mais ou menos por um ou outro livro, pela televisão, pela internet, por familiares, etc. Há de se entender de que, por mais que uma ou outra instância possa ter papel predominante na formação do aluno, todos o fazem em algum grau e, neste artigo, direciono minha atenção para o livro didático e para aqueles que, como eu, acreditam sê-lo fundamental ${ }^{6}$ para transformar a sociedade de forma justa e positiva.

\section{CONTEÚDO E DISCURSO NOS LIVROS DIDÁTICOS}

Entendendo o livro não só como instrumento, mas também como potencial de formação é que parto agora para a análise específica de uma amostragem de livros selecionados da Escola Estadual Effie Rolfs, escola-referência na cidade de Viçosa, em Minas Gerais. Busquei explorá-los não com intuito meramente crítico, mas também de atentar a respeito do caráter ideológico presente nas obras e incitar o corpo docente a exigir livros mais inclusivos, diversos e democráticos/plurais, que contemplem com maior exatidão a diversidade de sujeitos presentes em nossas escolas e em nosso País. Tomei de objeto os livros de Ciências, Biologia e Português (ensino fundamental e médio). Não significa que foram somente nestes que os conteúdos e ilustrações apresentem desacordos com os documentos nacionais analisados ou contenham carga ideológica não coerente com o projeto democrático da escola. Por questões de tempo e limitação da pesquisa é que tais livros adotados pela escola em questão foram selecionados.

A análise do material tem como base as recomendações e critérios já discutidos acima, presentes no edital do PNLD e seu catálogo para o ensino médio, além dos Parâmetros Curriculares Nacionais - Temas Transversais. Nos editais, o que foi levado em consideração para a pesquisa foram as recomendações e diretrizes anti-sexistas, anti-homofóbicas e sobre a inclusão da diversidade e representação ampla da multiplicidade brasileira. Os critérios de eliminação também

Se a literatura tem a pretensa "[...] missão de civilizar o homem na medida em que vai insinuando melhores formas de vida" (FACCO, 2009, p. 328), é preciso que se liberte do senso comum moralizador que alimenta este jogo de poder envolvido nos livros didáticos e suas representações de um mundo higienizado. 


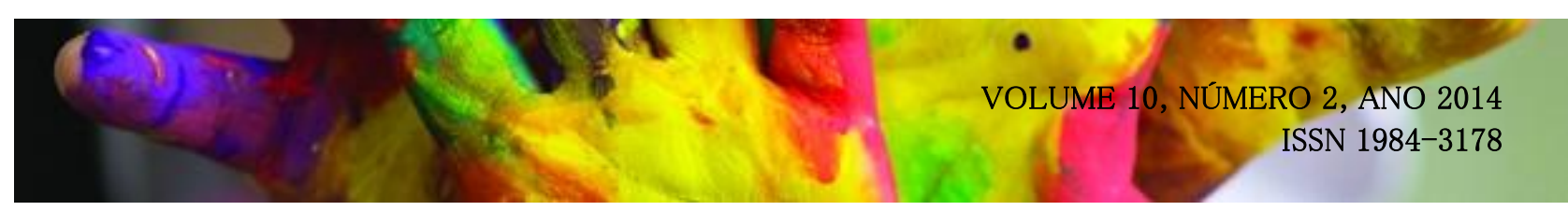

seguiam esta linha e definiam qual deveria ser o formato e conteúdo dos livros (como pro exemplo em seus princípios gerais onde constam os itens: Promover positivamente a imagem da mulher; abordar a temática de gênero, da não-violência contra a mulher; Incentivar a ação pedagógica voltada para o respeito e valorização da diversidade, etc.)

A análise foi feita em livros de Ciências, Português e Biologia e escolhidos através do PNLD pela escola Effie Rolfs. Os demais livros não foram analisados por razão de limitações da pesquisa aqui empreitada, no caso, tempo e abrangência definida (as linhas dos editais das outras disciplinas só servem para demonstrar a estrutura do programa e seus preceitos, e apontar para novas análises e abordagens dos docentes na respectiva área). Busquei exemplos claros onde não só ilustrações, mas também os conteúdos contrariavam os preceitos éticos básicos dos documentos do PNLD e PNLEM analisados, articulando-os nas discussões de gênero e sexualidade expostas aqui, de forma a mostrar como o livro contribui para acirrar as discriminações já presentes em nossa sociedade, não somente valorizando seu caráter heterossexual, mas invisibilizando outras formas possíveis de ser/estar, ao mesmo tempo que enrijece seu próprio núcleo, centrando a heterossexualidade em padrões específicos que todos devem seguir se não quiserem ser ridicularizados e/ou cair no ostracismo. Mostrarei a seguir fragmentos textuais e uma imagem retirados dos livros e tentarei expor como elas se distanciam das recomendações inclusivas presentes no PCN - Temas Transversais, editais e catálogos do PNLD.

Gostaria de começar contrapondo duas exposições do capítulo 15 de um livro de Ciências do ensino fundamental, $8^{\circ}$ ano ${ }^{7}$ : O capítulo trata do nascimento, diferenciação e puberdade entre o sexo masculino e feminino. As páginas 181 a 184 tratam do tópico "De menino a homem", título já em si complicado pela idéia simplificada que traz de tal passagem ser interpretada como meramente biológica e desconsiderando a construção social do gênero, apontando o título a uma sequiência linear e cronológica que não depende de certos percalços culturais para se concretizar. Porém, o que chama a atenção neste capítulo foi o tratamento dado, de forma diferenciada, às questões genitais e reprodutivas. Na página 184, ao tratar da puberdade, o livro diz: "Dois processos importantes que ocorrem na puberdade são o aparecimento do desejo sexual e o início da produção de

\footnotetext{
${ }^{7}$ Júnior, 2009, p. 181-186
} 


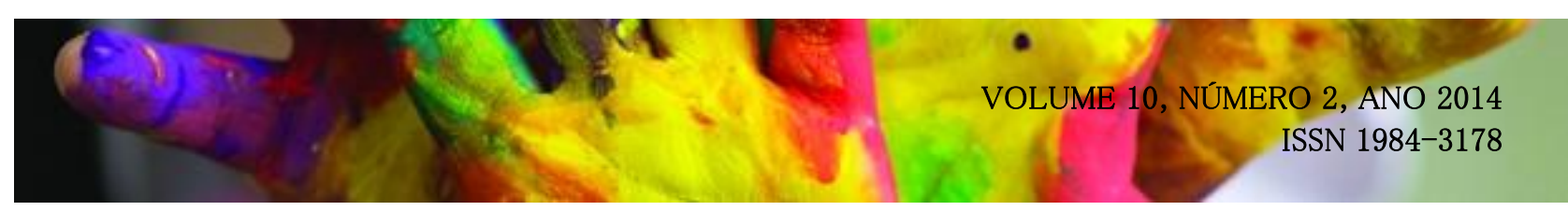

espermatozóides - células reprodutivas masculinas." E após abordar o desejo sexual, dilatação e ereção do pênis, continua: "Se houver estímulo tátil (masturbação) ou uma relação sexual, ocorrerá a ejaculação isto é, a expulsão de sêmen." O negrito, inclusive, sobre a palavra "ejaculação" é própria do livro. Após informações pontuais sobre o sêmen (tais como produção e volume), a única menção à reprodução sexuada acontece de forma incompleta, pois ao final, o texto conclui: "Homens que produzem menos de 20 milhões de espermatozóides por mililitro de sêmen são considerados inférteis." Somente a infertilidade é mencionada, ou seja, não há clara definição de o que é ser fértil e o que isso implica. Não se menciona a gravidez ou o papel do homem na reprodução humana. Na página 186, há o tópico “A primeira menstruação" no sub-capítulo nomeado "De menina a mulher", novamente implicando o determinismo biológico no crescimento da menina, implicando que ela se torna mulher por um processo supostamente natural e simples, como o título indica. O tópico se inicia informando que na puberdade, os ovócitos poderão se tornar óvulos, “... o que indica que elas já tem condições físicas para gerar bebês”. Após explicitar não só o caráter genético, mas também que a decisão de gerar um filho depende da maturidade psicológica e emocional dos pais, o tópico continua discorrendo somente sobre a fertilização, indicando que as transformações ocorridas no corpo feminino durante essa época se caracterizam pelo amadurecimento de células que gerarão ovócitos e crescimento de um tecido vascular no útero, tecido este que receberá um possível ovócito fértil.

Ao não haver fertilização, conclui, há a menstruação, sendo a primeira delas chamada de menarca. Ora, o que caracteriza esta distinção em ambos os tratamentos? Quem detém o genital masculino pode ter prazer enquanto quem detém o genital feminino só tem como opção ser fertilizada, de forma passiva e inescapável, pois, invariavelmente, seu corpo se desenvolve com tal intuito? Enquanto o tópico sobre o órgão masculino fala de prazer, ereção, ejaculação, estímulo e relação sexual, ao falar da sexualidade feminina, só delibera à mulher a meta de atingir a "maturidade biológica, psicológica e emocional" para então, poder ter um bebê. Pergunto-me se as mulheres que optam por não terem filhos são consideradas imaturas ou incapazes psicologicamente ou até mesmo emocionalmente desequilibradas, como o livro deixa a entender. Não há, nestas abordagens biológicas presentes no livro, de forma alguma, traços que indiquem a “... construção de 


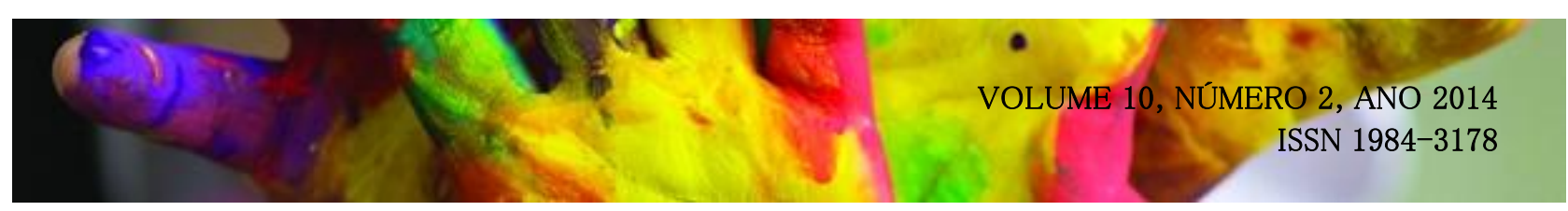

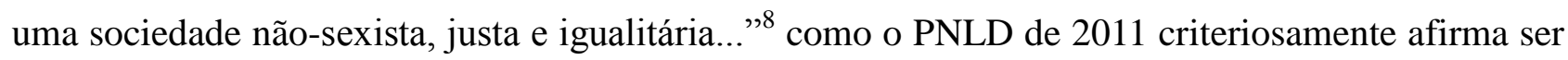
necessário como princípio geral.

Passemos à análise do livro de Biologia ${ }^{9}$ do ensino médio, escolhido através do PNLD pela escola Effie Rolfs. Nas páginas 134 e 135, incorrem-se as mesmas exposições já discutidas anteriormente, porém, ficando mais explícito a heteronormatividade que caracteriza a discussão. $\mathrm{O}$ sétimo tópico da página 134 da unidade 3, "Reprodução, Embriologia e Histologia", após caracterizar a constituição do sistema genital masculino, afirma: "Quando o homem é estimulado no ato sexual, seu pênis fica ereto e rígido. Isso ocorre devido ao afluxo de sangue, que preenche os espaços existentes no tecido cavernoso desse órgão. Assim, o pênis pode ser introduzido na vagina".

No tópico "Sistema genital feminino", não há menção ao estímulo sexual nem ejaculação feminina, somente ao ato passivo da fertilização: “O espermatozóide penetra o ovócito II, que finaliza a meiose formando o óvulo por um curto intervalo de tempo." O tratamento desigual de gênero/sexo acontece novamente no texto e, implicitamente, a sexualidade divergente é invisibilizada pois aquele e aquela que não optarem pelo sexo heterossexual (claramente explícito acima), não encontrão espaço para suas representações sexuais no livro e, conseqüentemente, na sociedade. Não há menção da dimensão do prazer para além da reprodução ou da escolha por diferentes métodos de concepção. O prazer, a sexualidade e a afetividade homoafetiva não estão presentes e não encontra espaço para representação, o que leva a pergunta do que ocorre quando algum aluno ou aluna percebe ter desejos diferentes dos demais colegas e nem no livro encontra apoio para se descobrir sem preconceitos.

Fora a fecundação, não se fala de sexo sem gravidez ou gravidez sem sexo. Não faltam exemplos que apontam novamente a esta hegemonia da heterossexualidade. Na página 139 do mesmo livro, ao falar de métodos contraceptivos, após explicarem o papel da camisinha no ato

\footnotetext{
8 Edital do Programa Nacional do Livro Didático (p. 36), o edital completo está disponível nas referências bibliográficas.

${ }^{9}$ Lopes;Rosso, 2005, p. 134-139.
} 


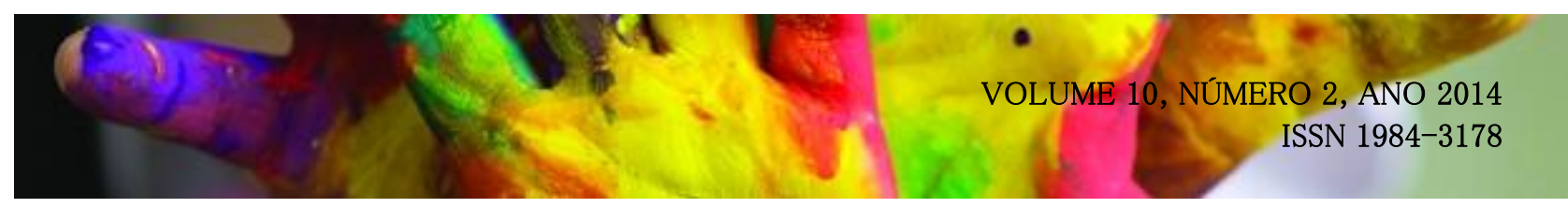

sexual (camisinha masculina, no caso), orienta-se: “Após a ejaculação, o pênis deve ser retirado do corpo feminino enquanto ainda estiver ereto." E em seguida, ao falar da camisinha feminina, explicando seu uso, o livro afirma: "O pênis deve penetrar no dispositivo." Deixo claro minhas considerações a respeito deste terreno mais explícito da sexualidade onde o livro demarca como prazeroso para uns e inescapável para outras. Há sempre a referência do feminino como receptor, como algo a ser penetrado enquanto ao masculino cabe ser o altivo e ativo. Fica claro nesta abordagem biológica o caráter normativo da sexualidade que delimita o âmbito de atuação dos dois sistemas genitais como naturais um para o outro. As outras configurações sexuais, além do sistema pênis-vagina, explícito do livro, não são sequer mencionadas sendo, portanto, relegadas a inexistência.

Nos livros de $8^{\circ}$ e $9^{\circ}$ ano de Português ${ }^{10}$, nos capítulos 2 e 3 , nomeados respectivamente, "Nas asas do coração" e "As formas de amor", a heteronormatividade se articula através do texto e das imagens proferidas nas páginas iniciais do capítulo.

Para ilustrar o argumento, tenho como exemplo a figura 1. A pintura se chama "O topo do mundo". O texto decorrente limita a afetividade heterossexual que, como a pintura demonstra, reina incontestável. Acima de tudo está o homem e a mulher, predestinados à reinar por sobre o mundo. Nota-se também a configuração corporal da mulher na pintura, de costas, com a mão no peito e entreolhando sobre seu ombro. Dá uma idéia de alguém a ser conquistada, é dócil e aparenta esperar uma salvação pois sua mão no peito demonstra desamparo. O livro dá a entender mais uma vez o feminino sob a ótica da submissão, propensão a ser completado por outrem.

$10 \quad$ Cereja;Magalhães, 2009. 

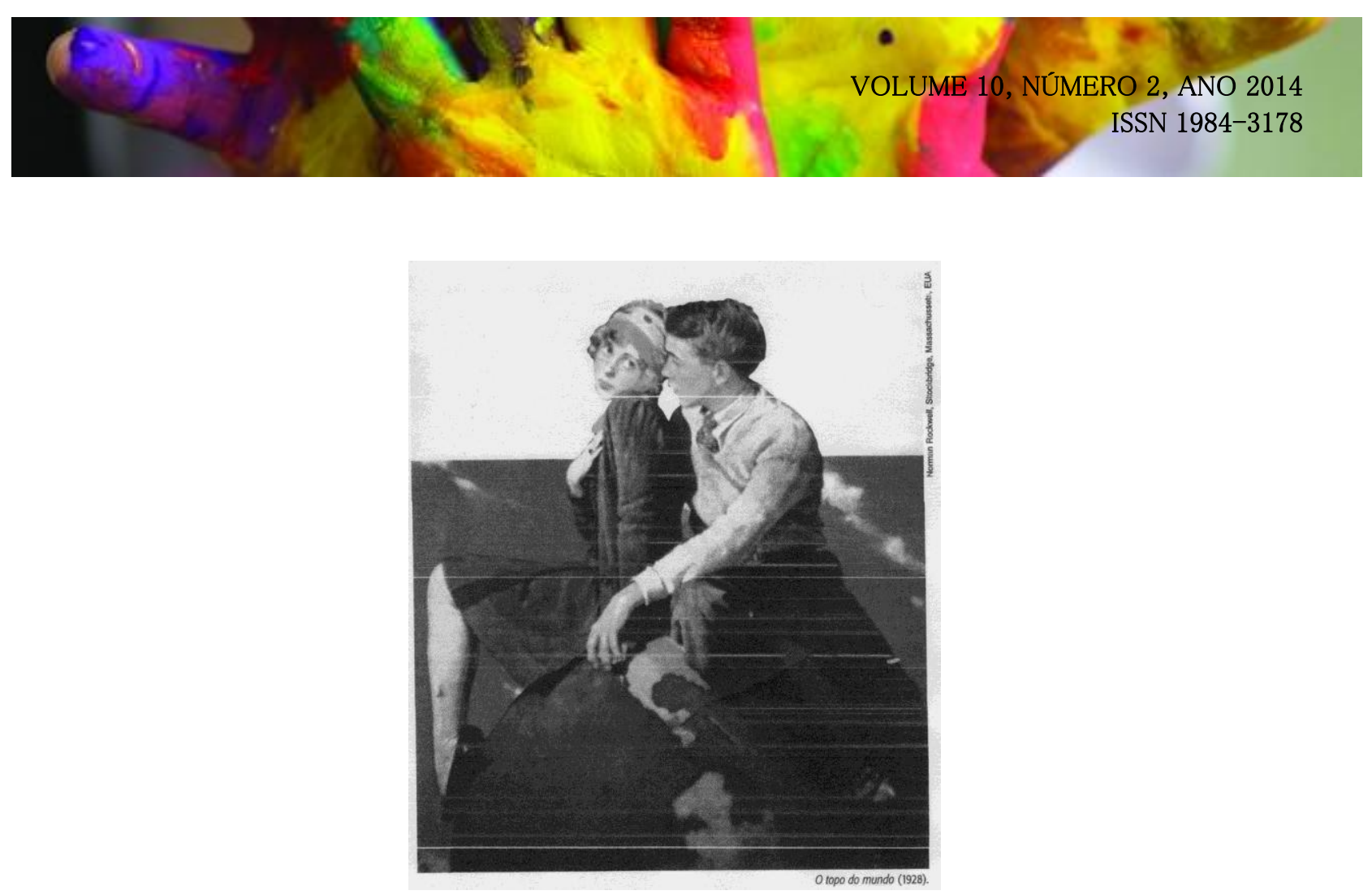

FIGURA 1 - O Topo do Mundo.

Fonte: CEREJA; MAGALHÃES. Português e linguagens: $8^{\circ}$ ano. (2009)

O capítulo 3, intitulado "As formas de amor", menciona em seu texto inicial o dilema de uma garota que se vê tendo sentimentos por três garotos diferentes e está confusa em razão disto. As duas figuras existentes no texto são de casais heterossexuais em situações românticas também, ora assistindo o pôr do sol abraçados, ora dançando com os corpos próximos uns ao outros. Perguntome então que "formas" de amor são essas quando o capítulo só ilustra uma: a heterossexual. Apesar do foco do trabalho não ser em configurações relacionais, cabe aqui uma observação sobre as pressuposições monogâmicas presentes no texto, ilustradas pela confusão de uma personagem que não se sente "completa" enquanto não escolher apenas um objeto de afeição. Não há a possibilidade dela viver outro formato de afetividade se não o monogâmico, não há no livro nenhuma menção às inúmeras formas de relacionamentos presentes e conhecidas em nossa sociedade como as relações abertas, o amor livre, o poliamor, os casamentos em casas separadas, etc.

Será que as "asas do coração" só batem quando um rapaz e uma moça se encontram? Será o 


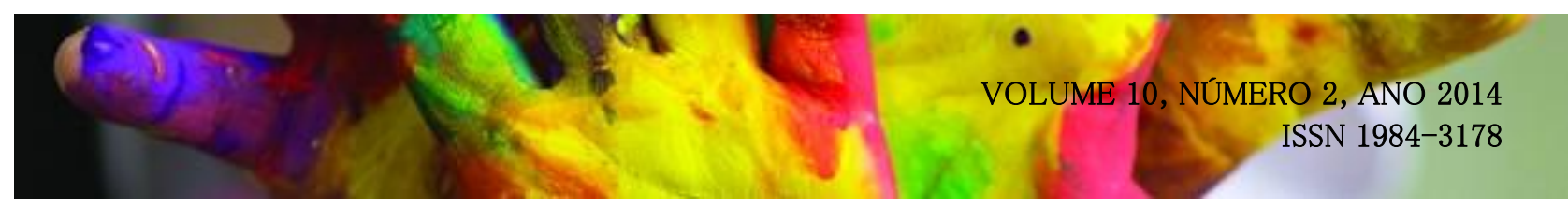

desejo, prazer, amor e afetividade sentimentos exclusivos de alguns e não abrangentes a todos? Louro (2010, p. 135) constata que tais sentimentos são representados, na quase totalidade dos livros didáticos analisados em sua pesquisa, sempre pertencentes ao reino heterossexual. É um pressuposto exclusivo que nega a potencialidade do amor entre sujeitos que buscam como objetos amorosos alguém do seu próprio sexo. Todo o mundo deve servir de palco para esta forma compulsiva heterossexualizada, única forma explicitada nos livros, de afetividade?

Para finalizar a parte empírica deste trabalho, me propus exercitar uma "matemática da desigualdade" no livro de Português para o ensino médio ${ }^{11}$. Ao contabilizar quantas figuras (de representações humanas graficamente visíveis como masculinas ou femininas encontradas no livro: fotos, charges, ilustrações, etc.) presentes no livro em questão, chegou-se no seguinte resultado: existem 127 ilustrações representando figuras masculinas e 45 representando figuras femininas. E se passarmos a um recorte de raça-etnia, constatou-se que destas 127 representações masculinas, 2 ilustravam homens negros e das 45 mulheres, apenas uma era negra.

\section{CONCLUSÕES E REFLEXÕES}

O edital do PNLD de 2011, ao tratar dos princípios éticos na construção cidadã e convívio republicano, afirma que as obras que veicularem estereótipos e preconceitos de orientação sexual estarão excluídas do programa. Eis então uma boa estratégia que as editoras podem encontrar para evitar a exclusão: para não incorrer no risco de estereotipar ou veicular preconceitos de ordem sexual e afetiva, sequer mencionam a existência de formas alternativas à heterossexualidade ou às diferentes configurações identitárias de gênero e/ou sexualidade. É uma boa estratégia de mercado, porém, onde está o convívio social e a cidadania então? Ao estudarem estes livros, alunas e alunos estão constantemente esbarrando em representações já existentes em seu meio, porém, quando tais modelos não correspondem à realidade de um ou outro, como ele ou ela se sentirão percebendo que não se encaixa com a realidade dos demais, representadas não só nos livros, mas nos filmes, novelas

11 Maia, 2005. 


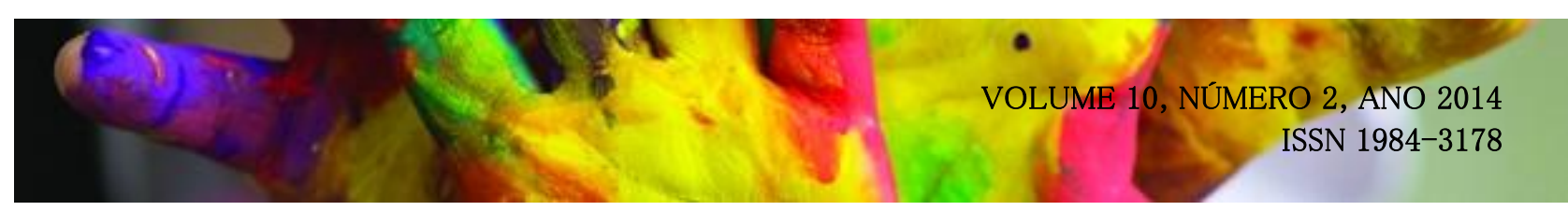

e no dia a dia? Facco traz luz ao problema que a obliteração da diversidade e representação nos livros pode trazer ao processo educativo de alunas e aluno, pois enquanto os alunos e alunas se vêem representados nos livros, vêem seus desejos e afetividades presentes, “[...] os/as estudantes homossexuais não encontram esses modelos, o que acarreta, na maioria das vezes, um sentimento de inadaptação, de inadequação à sociedade e ao mundo em geral.” (FACCO, 2009, p. 331). Portanto não é somente a má publicização que gera efeitos perversos na educação, mas também a falta de esclarecimento, de explicitação, de representatividade.

Chamo atenção apenas para o fato de que um programa, por mais progressista que seja, não dá conta de articular os diversos interesses que tramitam entre as escolas, o mercado editorial e o governo. Não podemos depender apenas de recomendações vindas de cima, mas devemos também repensar o papel do corpo docente no tratamento destes livros. Como recomenda o livro de conteúdo do CLAM "Gênero e Diversidade na escola", seria interessante a pesquisa e crítica dos educadores com intuito de exigir das editoras maior atenção em seu conteúdo, de forma a não contribuir para manter e/ou expressar as desigualdades já presentes na arena pública ${ }^{12}$.

Não só a crítica e pesquisa, mas também a participação de representantes dos movimentos sociais e estudantes que trabalhem o tema da diversidade na educação poderiam contribuir efetivamente para avaliar as obras e fazer valer os critérios progressistas que estas obras deveriam promulgar mas que infelizmente não acontece. Suas participações como avaliadores e a cobrança em cima dos que já compõe os funcionários das editoras são medidas para garantir a inclusão da diversidade e visibilidade das expressões identitárias nas obras que participem do PNLD. O esclarecimento e a visibilidade contribuem para que a heteronormatividade monolítica se fragilize, pois é um processo que

“[...] adquire consistência (e também invisibilidade) exatamente porque é empreendido de forma continuada e constante (muitas vezes, sutil) pelas mais diversas instâncias sociais. Os discursos mais autorizados nas sociedades contemporâneas repetem a normal regulatória

12 Dentro das recomendações do material feito pelo CLAM (2009, p. 33), é preciso atentar ao espaço escolar, quem o compõe, quais relações ali estão presentes, quem tem voz ou não tem, enfim, como está e quão valoriada é a diversidade. Deve-se perceber que ainda há sub-representações de mulheres e outras raças-etnias nos livros. As abordagens dos livros tendem a expressar desigualdades reais, perpetuando a hierarquia e a desigualdade de gênero e outros marcadores sociais. 


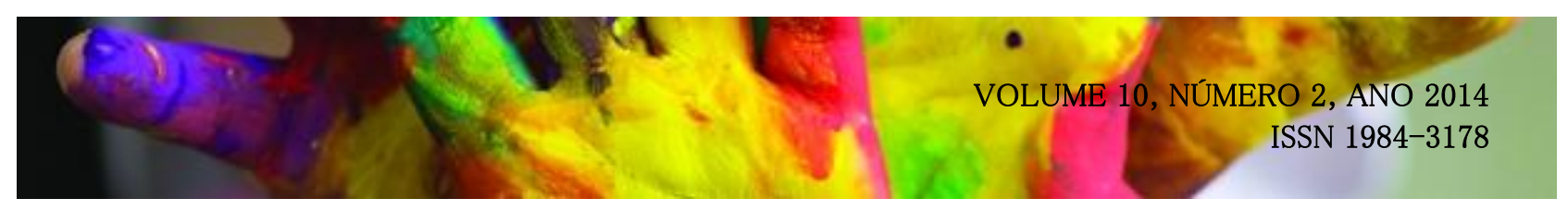

que supõe um alinhamento entre sexo-gênero-sexualidade.” (LOURO, 2009, p. 90).

Se a heteronormatividade paira acima das vontades, se cristalizando como algo natural frente a nós, é esta legitimidade que necessita ser contestada ${ }^{13}$. A heteronormatividade não é criticada no senso comum por ser entendido através de fenômenos reificados, “[...] coisas, isto é, em termos não humanos ou possivelmente super-humanos. Outra maneira de dizer a mesma coisa é que a reificação é apreensão dos produtos da atividade humana como se fossem algo diferente de produtos humanos, como se fossem fatos da natureza, resultados de leis cósmicas ou manifestações da vontade divina." (BERGER; LUCKMANN, 1985, p. 122-123). Essa reificação está presente nos discursos do livro didático. O discurso textual e imagético dos livros didáticos, pensando com Fairclough (2001, p. 91) constituem e moldam o mundo. Direta ou indiretamente, agem sobre as estruturas sociais, podendo mantê-las ou modificá-las, dependendo do contexto histórico e do momento social.

O livro didático é um propulsor de ideologias, e tal como a escola, segundo Althusser (1980) é um vetor e aparelho disciplinador do Estado (principalmente desde a obrigatoriedade do ensino médio). Assim, precisamos ficar atento para o que ele veicula. Atento para a necessidade de pesquisa da produção textual e semiótica e como elas se articulam no livro didático, pensar o impacto que este tem na vida de alunos e alunas e quais e como estão sendo tratados os temas atuais de nossa sociedade.

\section{REFERÊNCIAS BIBLIOGRÁFICAS}

ALTHUSSER, Louis. Posições II. Rio de Janeiro: Edições Graal, 1980.

BERGER, Peter L; LUCKMANN, Tomas. A Construção Social da Realidade: Tratado de Sociologia do Conhecimento. Petrópolis: Vozes, 1985.

BUTLER, Judith P. Problemas de Gênero: Feminismo e Subversão da Identidade. Rio de

\footnotetext{
13 Guacira contesta esta naturalização em seus escritos: “[...] as práticas rotineiras e comuns, os gestos e as palavras banalizados que precisam se tornar alvos de atenção renovada, de questionamento e, em especial, de desconfiança. A tarefa mais urgente talvez seja exatamente essa: desconfiar do que é tomado como "natural” (LOURO, 2010, p. 63).
} 


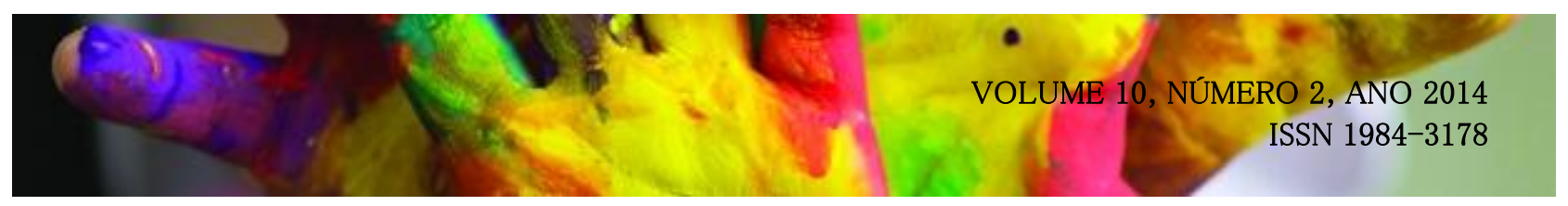

Janeiro: Civilização Brasileira, 2008.

CEREJA, William R; MAGALHÃES, Thereza C. Português e linguagens: $8^{\circ}$ ano. São Paulo: Atual, 2009.

CEREJA, William R; MAGALHÃES, Thereza C. Português e linguagens: $9^{\circ}$ ano. São Paulo: Atual, 2009.

DAYRELL, Juarez. A escola como espaço sócio-cultural. In: DAYRELL, Juarez. Múltiplos Olhares sobre Educação e Cultura. Belo Horizonte: UFMG, 1996.

FACCO, Lúcia. As "Diferenças" na Literatura Infantil e Juvenil nas Escolas: para entendê-las e aceitá-las. In: JUNQUEIRA, Rogério Diniz. Diversidade Sexual na Educação: problematizações sobre a homofobia nas escolas. Brasília: Ministério da Educação, Secretaria de Educação Continuada, Alfabetização e Diversidade, UNESCO, 2009.

FAIRCLOUGH, Norman. Discurso e mudança social. Brasília: Editora Universidade de Brasília, 2001.

FELIPE, Jane; BELLO, Alexandre Toaldo. Construção de Comportamentos Homofóbicos no Cotidiano da Educação Infantil. In: JUNQUEIRA, Rogério Diniz. Diversidade Sexual na Educação: problematizações sobre a homofobia nas escolas. Brasília: Ministério da Educação, Secretaria de Educação Continuada, Alfabetização e Diversidade, UNESCO, 2009.

FURLANI, Jimena. Mulheres só fazem amor com homens? A Educação Sexual e os relacionamentos entre pessoas do mesmo sexo. Pro-Posições, Campinas, v. 19, n. 2 (56), p. 111131, maio/ago, 2008.

BRASIL. Catálogo de Português do PNLEM, 2009. Disponível em: http://www.fnde.gov.br/index.php/arq-livro-didatico/1999catalogolinguaportuguesapnlem2009/download. Acesso em: 16 jul. 2010.

BRASIL (SECAD/MEC, CLAM). Gênero e Diversidade na Escola: Formação de professoras/es em gênero, sexualidade, orientação sexual e relações étnico-raciais. Livro de conteúdo. Brasília: SPM, 2009. Disponível em: http://www.e-clam.org/downloads/GDE_VOL1versaofinal082009.pdf. Acesso em: 05 jul. 2010.

BRASIL (SECRETARIA DE EDUCAÇÃO FUNDAMENTAL). Parâmetros Curriculares Nacionais: Terceiro e quarto ciclos do ensino fundamental - Temas Transversais. Disponível em: http:/portal.mec.gov.br/seb/arquivos/pdf/ttransversais.pdf. Acesso em: 10 jul. 2010.

GOVERNO DO ESTADO DE SANTA CATARINA. Considerações sobre análise e escolha de livros. Disponível em: http://www.sed.sc.gov.br/secretaria/documentos/doc_download/234consideracoes-sobre-livro-diatico. Acesso em: 14 jul. 2010. 


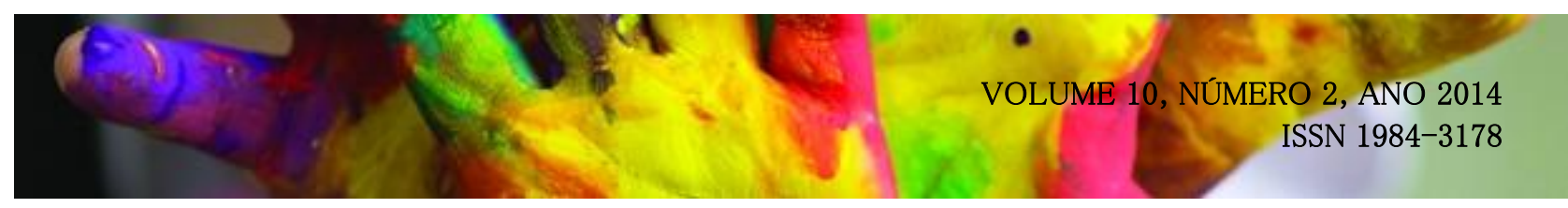

BRASIL. Edital do Programa Nacional do Livro Didático 2011 - Anos Finais. Disponível em: http://www.fnde.gov.br/index.php/arq-livro-didatico/4439-

editalpnld2011versaoconsolidada14abril/download. Acesso em: 16 jul. 2010.

BRASIL. Edital do Programa Nacional do Livro Didático 2012 - Ensino Médio. Disponível em: http://www.fnde.gov.br/index.php/arq-livro-didatico/4130-

editalpnld2012ensinomedioretificado/download. Acesso em: 16 jul. 2010.

JÚNIOR, José Trivelatto... [et al]. Ciências: natureza e cotidiano - $\mathbf{8}^{\mathbf{0}}$ ano. São Paulo: Renovada, 2009.

JUNQUEIRA, Rogério Diniz. 2009. Homofobia nas escolas: um problema de todos: In:

JUNQUEIRA, Rogério Diniz. Diversidade Sexual na Educação: problematizações sobre a homofobia nas escolas. Brasília: Ministério da Educação, Secretaria de Educação Continuada, Alfabetização e Diversidade, UNESCO.

LIONÇO, Tatiana; DINIZ, Debora. Homofobia, silêncio e naturalização: por uma narrativa da diversidade sexual. In: LIONÇO, Tatiana; DINIZ, Debora. Homofobia \& Educação: um desafio ao silêncio. Brasília: LetrasLivres, EdUnB, 2009.

LOURO, Guacira Lopes. Gênero, sexualidade e educação: uma perspectiva pós-estruturalista. Petrópolis: Vozes, 2010.

LOURO, Guacira Lopes. Heteronormatividade e Homofobia. In: JUNQUEIRA, Rogério Diniz. Diversidade Sexual na Educação: problematizações sobre a homofobia nas escolas. Brasília: Ministério da Educação, Secretaria de Educação Continuada, Alfabetização e Diversidade, UNESCO, 2010.

MAIA, João Domingues. Português: volume único. 2. ed, São Paulo: Ática, 2005.

NUNES, Jordão Horta. A sociolingüística de Goffman e a comunicação mediada. Tempo soc., São Paulo, v. 19, n. 2, p. 253-286, nov. 2007.

SANTOS, Luiz Henrique. Heteronormatividade e Educação. Disponível em:

http://www.britishcouncil.org.br/download/LuisHenrique.pdf. Acesso em: 13 jul. 2010

LOPES, Sônia; ROSSO, Sérgio. Biologia: volume único. São Paulo: Saraiva, 2010;

SPARGO, Tamsin. Foucault e a Teoria Queer. Rio de Janeiro: UFJF, 2006.

TROTSKY, Leon. Cultura e socialismo. In: MIRANDA, Orlando (Org.). Leon Trotski: Política. São Paulo: Ática, 1981. 